\title{
ANALISIS UNDANG-UNDANG NOMOR 2 TAHUN 2017 TENTANG ORGANISASI KEMASYARAKATAN DALAM TEORI NEGARA HUKUM
}

\author{
Mahsun Ismail \\ Magister Ilmu Hukum Universitas Islam Indonesia, Email : mahsunismail09@gmail.com
}

\begin{abstract}
ABSTRAK
Berlakunya Undang-Undang Nomor 2 tahun 2017 tentang Organisasi Kemasyarakatan yang berasal Perpu Nomor 2 Tahun 2017 menjadi perhatian banyak pihak. Sebab hal tersebut berdampak terhadap dibubarkannya Hizbut Tahrir Indonesia (HTI), sebuah organisasi kemasyarakatan yang dianggap menjadi ancaman negara karena mengusung ideologi khilafah serta dianggap bertentangan dengan ideologi bangsa yaitu Pancasila. Dalam konteks ini, keberadaan Undang-Undang Nomor 2 tahun 2017 terdapat pihak yang mendukung (pemerintah), namun adapula yang tidak mendukung sebab dianggap menimbulkan dampak terhadap demokrasi di Indonesia, dikarenakan Undang Undang tersebut hanya mengakomodir sebagian kepentingan yang ada di negara ini dan tidak meperhatikan secara keseluruhan aspirasi masyarakat Indonesia. Bahwa dalam Undang-Undang tersebut pencantuman asas contrarius actus, namun turut menimbulkan kekeliuruan secara normatif, sebab organisasi masyarakat yang dianggap melanggar ideologi negara hanya dapat dibubarkan secara adil dan benar melalui mekanisme peradilan, apalagi bila status ormas tersebut telah berbadan hukum. Oleh sebab itu, Undang Undang tersebut telah mengabaikan salah satu prinsip due process of law yang dianut oleh negara hukum yang dimana pembubaran ormas tidak melalui mekanisme peradilan. Artikel ini akan mengulas mengenai keberadaan Undang-Undang Nomor 2 tahun 2017 serta dinamika yang ditimbulkannya, khususnya dalam konteks teori negara hukum.
\end{abstract}

Kata-kata kunci : Undang-Undang; Organisasi Kemasyarakat; negara hukum.

\section{ABSTRACT}

The enactment of Law Number 2 of 2017 concerning Community Organizations originating from Perpu Number 2 of 2017 concerns many parties. Because this has an impact on the dissolution of Hizb ut-Tahrir Indonesia (HTI), a community organization that is considered to be a threat to the state because it carries out the Caliphate ideology and is considered contrary to the ideology of the nation (Pancasila). In this context, the existence of Law Number 2 of 2017 has parties that support (the government), but there are those who do not support because it is considered to have an impact on democracy in Indonesia, because the Law only accommodates some interests in this country and does not pay attention the overall aspirations of the Indonesian people. Whereas in the Act the inclusion of the principle of contrarius actus, but also contributes to the normalization of religion, because community organizations that are considered to violate the ideology of the state can only be disbanded fairly and correctly through judicial mechanisms, especially if the status of the organization is legal. 
Therefore, the Law has ignored one of the principles of due process of law adopted by a legal state where the dissolution of mass organizations is not through a judicial mechanism. This article will review the existence of Law Number 2 of 2017 as well as the dynamics that it creates, especially in the context of the rule of law theory.

Keywords: Constitution; Community Organization; state law.

\section{PENDAHULUAN}

Negara Kesatuan Republik Indonesia memberikan kebebasan kepada rakyatnya untuk berkumpul dan berserikat sebagaimana diatur dalam Undang-Undang Dasar 1945. Organisasi Kemasyarakatan telah dijamin oleh Undang-Undang sehingga dalam pelaksanaan demokrasi berjalan sesuai dengan fungsinya, yang dimana Organisasi Kemasyarakatan sebagai, penyalur kegiatan, pembina dan pengembangan, penyalur aspirasi, pemberdayaan masyarakat, pemenuhan pelayanan sosial, memelihara dan menjaga memperkuat persatuan dan kesatuan bangsa, memelihara dan pelestari norma, nilai dan etika dalam kehidupan bermasyarakat, berbangsa dan bernegara. Saat ini, berdasarkan data yang tercatat oleh Kementerian Hukum Dan Hak Asasi Manusia pada tahun 2017 Organisasi Kemasyarakatan atau disingkat Ormas berjumlah 344.039 Ormas.

Organisasi Kemasyarakatan di Indonesia memiliki visi dan misi yang beragam dan didasari oleh latar belakang yang berbeda. Seperti, organisasi pendidikan, kesehatan, pertanian, organisasi produksi, organisasi politik, serikat pekerja, organiasi pemelihara yang keseluruhannya berpatokan kepada pancasila dan UUD 1945 pasal 28e ayat 3. Adapun organisasi yang dimaksud oleh masyarakat yang menganggap bahwa hal itu merupakan wadah untuk berkumpul, berserikat dan menyampaikan pendapatnya meerupakan ruh demokrasi yang dirasakan oleh seluruh rakyat Indonesia.

Lahirnya dan berkembangnya Organisasi Kemasyarakatan di Indonesia merupakan suatu cerminan demokrasi yang berdasarkan prinsip-prinsip dari negara hukum yang tertuang dalam Undang-Undang Dasar Negara Republik Indonesia pasal 1 ayat 3 yang menyatakan bahwa "Negara Indonesia adalah negara yang berdasarkan hukum". Pemerintah terus mengawasi Organisasi Kemasyarakatan dalam pergerakan untuk menghindari ketidakstabilan kehidupan berbangsa dan bernegara yang berdasarkan ideologi pancasila yang tetap mengutamakan kebhinekaan. Pancasila sebagai ideologi dituntut untuk tetap pada jati dirinya ke dalam 
(segi intristik) dan ke luar (segi ekstrintik). Ke dalam, Pancasila harus konsisten, koheren, koresponden. Ke luar, harus menjadi penyalur dan penyaring kepentingan, horizontal maupun vertikal. Pancasila sebagai ideologi dapat memperstukan kita secara politis, dapat mewakili dan menyaring berbagai kepentingan, mengandung pluralisme agama, dan dapat menjamin kebebasan beragama. Meskipun ada pihak yang tidak setuju dengan Pancasila sebagai ideologi, tapi sampai sekarang Pancasila tetap sebagai ideologi negara.

Ideologi memainkan peranan yang penting dalam proses dan memelihara integritas nasional, terutama di negara-negara yang sedang berkembang seperti Indonesia. Peranan tersebut tergantung pada kualitas yang dimiliki serta dapat diukur melalui tiga dimensi, yaitu kemampuan mencerminkan realitas hidup dalam masyarakat, idealisme yang terkandung, dan fleksibilitasnya terhadap perubahan-perubahan yang terjadi. Melalui ketiga dimensi tersebut dapat diteliti apakah ideologi itu mampu atau tidak memelihara relevansinya yaitu titik keseimbangan sebagai tempat bertemunya konsensus antara berbagai kelompok atau golongan-golongan. Krisis ideologi akan terjadi apabila titik keseimbangan tersebut hilang. Apabila terjadi, maka diperkirakan dapat mengancam integritas nasional dan persatuan nasional (Puslit IAIN Jakarta, 2000: 22-23). Sehingga pengawasan dan pengaturan wajib di lakukan oleh negara melalui peraturan perundang-undangan agar tidak menjadi ancaman bangsa negara.

Salah satu organisasi yang dianggap sebagai ancaman negara yang karena dianggap bertentangan dengan ideologi bangsa yaitu Pancasila adalah Hizbut Tahrir Indonesia (HTI), dimana tujuan dari organisasi HTI ingin membentuk negara yang berdasarkan kekhalifahan. Karena hal tersebut lahirlah Perpu Nomor 2 Tahun 2017 yang kemudian disahkan menjadi Undang-Undang Nomor 2 tahun 2017 dimana sebelumnya telah ada Undang-Undang Nomor 17 Tahun 2013 yang dianggap tidak bisa merespon organisasi masyarakat yang dianggap bertentangan dengan ideologi negara. Lahirnya Undang-Undang Nomor 2 tahun 2017 mengenai Organisasi Masyarakat, namun pembubaran HTI tidak melalui mekanisme-mekanisme peradilan yang dicitakan oleh negara hukum yakni melalui proses yang baik demi tujuan demokrasi yang seharusnya. Akan tetapi, respon pemerintah terhadap hal tersebut kemudian 
dirumuskan ke dalam Undang-Undang Nomor 2 Tahun 2013 tentang Organisasi Kemasyarakatan (Ormas).

Undang-Undang Ormas sendiri secara tidak langsung mengekang kebebasan berserikat seseorang. Dikarenakan prinsip awal pembentukan UU Ormas ini tidak berangkat dari nilai-nilai yang berkembang di masyarakat secara luas, dalam kenyataannya ketika Undang-Undang Ormas dibentuk tersebut hanya memperhatikan isu yang berkembang, sebagaimana yang tertuang dalam rumusan Undang-Undang Nomor 2 Tahun 2013 bahwa Undang-Undang ini tidak memperhatikan prosedur dalam proses peradilan ketika ormas dianggap telah bertentangan dengan idiologi negara Indonesia, maka Ormas tersebut dapat dibubarkan, dengan melihat hal tersebut Undang-Undang Ormas ini merupakan salah satu cerminan kekuasaan penuh pemerintah untuk memaksakan kehendak demi kepentingan segelintir atau sekelompok orang yang berada dilingkup pemerintahan.

Negara Hukum, HAM, dan Demokrasi merupakan salah satu konsepsi yang tidak dapat terpisahkan yang merupakan suatu rangkaian, dimana negara hukum merupakan suatu ide yang telah lama ada yang merupakan suatu titik tolak dari perlawanan atas kesewenang-wenangan dari masa lampau yakni antara kekuasaan raja dan rakyat tidak memiliki keseimbangan (Huda, 2005: 2). Konsepsi Demokrasi dari negara hukum bahwa hukum yang mengatur di dalam sebuah negara yang berdaulat merupakan hasil dari kedaulatan rakyat yang diperoleh secara demokratis. Dalam sistem demokrasi modern dewasa ini, sistem kekuasaan dalam kehidupan bersama biasa dibedakan dalam tiga wilayah atau domain, yaitu, negara (state), pasar (market), dan masyarakat (civil society). Ketiga domain kekuasaanya harus berjalan seiring dan sejalan, sama-sama kuat dan sama-sama saling mengendalikan satu sama lain, tetapi tidak boleh saling mencampuri atau dicampuradukkan. Jika kekuasaan negara terlalu dominan, demokrasi tidak akan tumbuh karena selalu didikte dan dikendalikan oleh negara dimana yang berkembang adalah ototarianisme (Asshiddiqie, 2016: 151). Maka dari itu, agar negara hukum berjalan sesuai arah dan tujuan dan tidak timbul kesewenang-wenangan, maka diperlukan batasan hukum dan juga menerapkan demokrasi yang berdasarkan dan merupakan cerminan dari ke tiga unsur kekuasaan tersebut. 


\section{PEMBAHASAN}

Salah satu cerminanan bahwa suatu negara damai yakni ketika negara tersebut didasarkan oleh suatu hukum yang mengatur seluruh kehidupan berbangsa dan bernegara, sebagaimana yang dikemukakan oleh Aristoteles "suatu negara yang baik ialah negara yang diperintah dengan konstitusi dan berkedaulatan hukum". Pihak yang memerintah dalam negara bukanlah manusia, melainkan pemikiran yang adil, dan kesusilaanlah yang menentukan baik buruknya suatu hukum. Manusia perlu dididik menjadi warga yang baik, berasusila, yang akhirnya akan menjelmakan manusia yang bersikap adil. Apabila keadaan semacam tersebut telah terwujud, maka terciptalah suatu "negara hukum", karena tujuan negara adalah kesempurnaan warganya yang berdasarkan atas keadilan. Jadi, keadilanlah yang memerintah dalam kehidupan bernegara.

Dalam perkembangannya, terdapat kolerasi yang jelas antara negara hukum yang bertumpu pada konstitusi, dengan kedaulatan rakyat yang dijalankan melalui sistem demokrasi. Dalam sistem demokrasi, partisipasi rakyat merupakan esensi dari sistem ini. Artinya, negara harus ditopang dengan sistem demokrasi. Demokrasi tanpa pengaturan hukum akan kehilangan bentuk dan arah, sedangkan hukum tanpa demokrasi akan kehilangan makna. Demokrasi cara paling aman mepertahankan kontrol atas negara hokum (Huda, 2005:1). Dengan demikian ketika negara itu berdasarkan hukum maka hal ini tidak terlepas dari namanya sebuah aturan yang tertulis atau aturan yang telah diperundangkan oleh negara tersebut, hal ini tidak terlepas dari kewenangan yang dimiliki oleh suatu lembaga negara yang berwenang dalam pembuatan undang-undang tersebut.

Prinsip-prinsip negara hukum selalu berkembang seiring dengan perkembangan masyarakat dan negara. Salah seorang profesor di Utrecht University membedakan dua macam negara hukum, yaitu negara hukum formil atau negara hukum klasik, dan negara hukum materiel atau negara hukum modern. Negara hukum formil menyangkut pengertian bersifat formil dan sempit, yaitu dalam arti peraturan perundang-undangan tertulis terutama. Tugas negara adalah melaksanakan peraturan perundangundangan tersebut untuk menegakkan ketertiban. Tipe negara tradisional ini dikenal dengan istilah negara penjaga malam. Negara hukum materil 
mencakup pengertian yang lebih luas termasuk keadilan didalamnya. Tugas negara tidak hanya menjaga ketertiban dengan melaksanakan hukum, tetapi juga mencapai kesejahteraan rakyat sebagai bentuk keadilan (welfarestate). Berdasarkan kecenderungan perkembangan negara hukum modern yang melahirkan prinsip-prinsip penting baru untuk mewujudkan negara hukum, maka terdapat dua belas prinsip pokok sebagai pilar-pilar utama yang menyangga berdirinya negara hukum. Kedua belas prinsip tersebut adalah : supermasi hukum (supremacy of law), persamaan dalam hukum (equality before the law), asas legalitas (due process of law), pembatasan kekuasaan, organ-organ penunjang yang independen, peradilan bebas dan tidak memihak, peradilan tata usaha Negara, Mahkamah Konstitusi (constitutional court), perlindungan hak asasi manusia, bersifat demokratis (democratische rechstsstaat), berfungsi sebagai sarana mewujudkan tujuan bernegara (welfare rechtsstaat), serta transparansi dan kontrol sosial.

Perkembangan prinsip-prinsip negara hukum tersebut dipengaruhi oleh semakin kuatnya penerimaan paham kedaulatan rakyat dan demokrasi dalam kehidupan bernegara menggantikan model-model negara tradisional. Prinsip-prinsip negara hukum (nomocratie) dan prinsip-prinsip kedaulatan rakyat (dijalankan secara beriringan sebagai dua sisi mata uang. Paham negara hukum yang demikian dikenal disebut sebagai negara hukum yang demokratis (democratische rechtsstaat) atau dalam bentuk konstitusional disebut constitusional democracy. Hukum dibangun dan ditegakkan menurut prinsip-prinsip demokrasi. Hukum tidak boleh dibuat, ditetapkan, ditafsirkan, dan ditegakkan dengan tangan besi berdasarkan kekuasaan semata (machtstaat), sebaliknya demokrasi haruslah diatur berdasar atas hukum. Perwujudan gagasan demokrasi memerlukan instrument hukum untuk mencegah munculnya mobokrasi yang mengancam pelaksanaan demokrasi itu sendiri.

Negara demokrasi modern berdiri di atas basis kesepakatan umum mayoritas rakyat tentang bangunan negara yang diidealkan. Organisasi negara diperlukan agar kepentingan-kepentingan mereka dapat dilindungi atau dipromosikan melalui pembentukan dan penggunaan mekanisme negara. Masyarakat suatu negara terdiri dari berbagai macam kelompok dengan kepentingan yang berbeda-beda yang jika tidak diatur dan diorganisasikan dengan baik akan saling berbenturan dan kembali pada kondisi pra negara. Maka salah satu fungsi negara adalah memenuhi 
kepentingan warga negara sekaligus melindungi kepentingan warga negara yang lain. Negara diberi kekuasaan untuk mempromosikan kepentingan warga negara yang lain. Negara diberi kekuasaan untuk mempromosikan kepentingan warga negara dan mengatur pemenuhan kepentingan tersebut atau bahkan membatasinya jika dapat merugikan kepentingan warga negara yang lain. Jika negara hanya mempromosikan kepentingan sekelompok warga negara saja, maka akan menjadi negara kelas yang melahirkan gerakan-gerakan sosialisme-komunisme.

Dalam sistem demokrasi modern dewasa ini, sistem kekuasaan dalam kehidupan bersama biasa dibedakan dalam tiga wilayah atau domain, yaitu negara (state), pasar (market), dan masyarakat (civil society). Ketiga domain kekuasaan tersebut memiliki logika dan hukumnya sendiri-sendiri. Ketiganya harus berjalan seiring dan sejalan, sama-sama kuat dan sama-sama saling mengendalikan satu sama lain, tetapi tidak boleh saling mencampuri atau dipercampuradukkan. Jika kekuasaan negara terlalu dominan, demokrasi tidak akan tumbuh karena selalu didikte dan dikendalikan oleh negara dimana yang berkembang adalah otoritarianisme. Jika kekuatan pasar terlalu kuat, melampaui kekuatan "civil society" dan negara, berarti kekuatan modal (capital) dan kaum kapitalis yang menentukan dalam kehidupan bermasyarakat dan bernegara. Demikian pula jika kekuasaan yang dominan adalah "civil society" sedangkan negara dan pasar lemah, maka yang akan terjadi adalah situasi "chaos", "messy", government-less", tanpa arah yang jelas (Asshiddiqie, 2016: 148-150).

Paham negara hukum tidak dapat dipisahkan dari paham kerakyatan. Sebab pada akhirnya, hukum yang mengatur dan membatasi kekuasaan negara atau pemerintah diartikan sebagai hukum yang dibuat atas dasar kekuasaan atau kedaulatan rakyat. Begitu tali-temali antara paham negara hukum dan kerakyatan, sehingga ada sebutan negara hukum yang demokratis atau democratische rectsstaat. Scheltema, memandang kedaulatan rakyat (democratie beginsel) sebagai salah satu dari empat asas negara hukum, di samping rechtszekerheidbeginsel, gelijkheid beginsel dan het beginsel van de dienendeoverheid. Dalam kaitannya dengan negara hukum, kedaulatan rakyat merupakan unsur material negara hukum, disamping masalah kesejahteraan rakyat. Di negara-negara Eropa Kontinental konsepsi negara hukum mengalami perkembangan yang cukup pesat, utamanya perkembangan terhadap asas legalitas yang semula diartikan 
sebagai pemerintahan berdasarkan atas undang-undang (wetmatigheid van bestuur), kemudian berkembang menjadi pemerintahan berdasarkan atas hukum (rechtmatigheid van bestuur). Terjadinya perkembangan konsepsi tersebut merupakan konsekuensi dari perkembangan konsepsi negara hukum materiil, sehingga kepada pemerintah diserahi tugas dan tanggung jawab yang semakin berat dan besar untuk meningkatkan kesejahteraan warganya. Akhirnya, kepada pemerintah diberikan pula ruang gerak yang semakin longgar yang cenderung melahirkan pemerintahan bebas (vrij bestuur) dengan disertai ruang kebijaksanaan yang longgar berupa freies ermessen.

Guna menghindari agar penggunaan kewenangan bebas (vrij bestuur) dan wewenang kebijaksanaan (freies ermessen) tersebut tidak disalahgunakan dan tetap berada dalam batas-batas hukum, maka kehadiran dan peranan hukum administrasi menjadi semakin penting dalam penyelenggaraan pemerintahan. Salah satu asas penting negara hukum adalah asas legalitas. Substansi dari asas legalitas tersebut adalah menghendaki agar setiap tindakan badan/pejabat administrasi berdasarkan undang-undang. Tanpa dasar undang-undang, badan/pejabat administrasi negara tidak berwenang melakukan suatu tindakan yang dapat merubah atau mempengaruhi keadaan hukum warga masyarakat.

Asas Legalitas berkaitan erat dengan gagasan demokrasi dan gagasan negara hukum (het democratish ideal en het rechtsstaats ideal). Gagasan demokrasi menuntut agar setiap bentuk undang-undang dan berbagai keputusan mendapatkan persetujuan dari wakil rakyat dan sebanyak mungkin memperhatikan kepentingan rakyat. Gagasan negara hukum menuntut agar penyelenggaraan kenegaraan dan pemerintah harus didasarkan kepada undang-undang dan memberikan jaminan terhadap hak-hak dasar terhadap rakyat yang tertuang dalam undang-undang. Menurut Sjachran Basah, asas Legalitas berarti upaya mewujudkan duet integral secara harmonis antara paham kedaulatan hukum dan paham kedaulatan rakyat berdasarkan prinsip monodualistis selaku pilar-pilar, yang sifat hakikatnya konstitutif. Penerapan asas legalitas, menurut Indroharto, akan menunjang berlakunya kepastian hukum dan berlakunya kesamaan perlakuan (Huda, 2005: 19-20). Terdapat korelasi yang jelas antara negara hukum yang bertumpu pada konstitusi dengan kedaulatan rakyat yang dijalankan melalui sistem demokrasi. Korelasi ini tampak dari 
kemunculan istilah demokrasi konstitusional. Dalam sistem demokrasi partisipasi rakyat merupakan esensi dari sistem ini. Dengan kata lain negara hukum harus ditopang dengan sistem demokrasi. Hubungan di antara keduanya tidak dapat dipisahkan. Demokrasi tanpa pengaturan hukum akan kehilangan bentuk dan arah, sedangkan hukum tanpa demokrasi akan kehilangan makna (Sarja, 2016: 31). Disebut sebgai "negara hukum yang demokratis", karena di dalamnya mengakomodasikan prinsip-prinsip negara hukum dan prinsip-prinsip demokrasi. Negara hukum yang demokratis adalah negara saling percaya antara rakyat dengan penguasa, sebagaimana diungkapkan Van der Pot Donner, yaitu "De rechtstaat is de staat van het wevarzids vertouwen atau negara hukum adalah negara kepercayaan timbal balik. Menurut Couwenberg terdapat lima asas demokratis yang melandasi negara hukum, yaitu: pertama, adanya asas hak-hak politik. Kedua, adanya asas mayoritas. Ketiga, adanya asas perwakilan. Keempat, adanya asas pertanggung- jawaban. Kelima, adanya asas publik (Sarja, 2016: 31).

Manifestasi demokrasi terhadap Undang-Undang Ormas, apabila memperhatikan hal-hal di atas, maka hal ini juga berlaku bagi negara Indonesia yang merupakan negara yang berdasarkan hukum sebagaimana amanat UUD 1945 pasal 1 ayat 3 yang berbunyi "Negara Indonesia adalah negara hukum". Ketika hal tersebut dijadikan dasar maka seluruh aturan dalam kehidupan negara yang berbingkai Pancasila itu harus berlandaskan akan hukum. Namun hal itu tidak terlepas dari aspirasi-aspirasi masyarakat dalam proses pembuatan sebuah undang-undang yang merupakan wujud dari adanya kedaulatan rakyat didalamnya dan hal ini nampak jelas terlihat dalam pasal 1 ayat 2 yakni kedaulatan berada ditangan rakyat dan dilaksanakan menurut undang-undang.

Perkembangan pesat demokrasi di Indonesia mengakibatkan seluruh komponen-komponen negara terdampak dengan adanya demokrasi di Indonesia, salah satu hal yang paling terlihat dengan adanya demokrasi adalah munculnya berbagai macam organisasi kemasyrakatan yang merupakan sebuah wadah bagi masyarakat namun untuk kebebasan tersebut tidak disalahgunakan maka diaturlah sebuah Undang-Undang yang mengatur tentang oraganisasi kemasyarakatan yakni UndangUndang Nomor 17 Tahun 2013 Tentang Ormas namun Undang-Undang ini dianggap belum sempurna dalam menjaga kehidupan berbagsa negara 
yang berlandaskan Pancasila dan tidak terakomodirnya asas contrarius actus dalam Undang-Undang yang lama, sehingga berakibat pada norma, larangan, dan sanksi serta prosedur hukum yang ada.

Dikeluarkannya Peraturan Pemerintah Pengganti Undang-Undang Nomor 2 tahun 2017 yang merupakan respon dari kegiatan-kegiatan beberapa Ormas yang dianggap menimbulkan konflik ditengah masyarakat karena bertentangan dengan Pancasila dan UUD 1945 dengan demikian terbitlah Perpu tersebut sebagai perluasan dari defenisi yang bertentangan dengan Pancasila. Dengan demikian melalui Menko Polhukam, Wiranto dalam pers rilisnya (12/7/2017) memberikan berbagai argumen terkait diterbitkannya Perpu yang menjadi cikal bakal dari perubahan Undang-Undang Ormas yang lama ada lima hal sebagai berikut: pertama, Perpu tersebut diterbitkan dalam rangka tugas pemerintah untuk melindungi segenap bangsa dan tumpah darah Indonesia. Kedua, Organisasi kemasyarakatan (ormas) di Indonesia yang saat ini mencapai 344.039 ormas, telah beraktivitas di segala bidang kehidupan, baik dalam tingkat nasional maupun ditingkat daerah, harus diberdayakan dan dibina, agar dapat memberikan kontribusi positif bagi pembangunan nasional. Ketiga, kenyataannya saat ini, terdapat kegiatan-kegiatan organanisasi kemasyarakatan (ormas) yang bertentangan dengan Pancasila dan Undang-Undang Dasar 1945, dan menjadi ancaman terhadap eksistensi bangsa, dengan telah menimbulkan konflik di masyarakat. Keempat, Undang-Undang Nomor 17 tahun 2013 tentang organisasi kemasyarakatan tidak lagi memadai sebagai sarana untuk mencegah meluasnya ideologi yang bertentangan dengan Pancasila dan Undang-Undang Dasar 1945, baik dari substantif terkait dengan norma, larangan, dan sanksi serta prosedur hukum yang ada. Antara lain tidak terwadahinya asas hukum administrasi contrarius actus yaitu asas hukum bahwa lembaga yang mengeluarkan izin atau yang memberikan pengesahan adalah lembaga yang seharusnya mempunyai wewenang untuk mencabut atau membatalkannya. Kelima, Selama ini, pengertian tentang ajaran dan tindakan yang bertentangan dengan pancasila dirusmuskan secara sempit yaitu hanya sebatas pada ajaran atheisme, marxisme dan leninisme. Padahal sejarah Indonesia membuktikan bahwa ajaran-ajaran lain juga bisa bertentangan dengan pancasila (Sarjito, 2017: 1).

Setelah dari berbagai argumentasi terkait lahirnya Perpu tersebut 
bahwa perpu termasuk salah satu bentuk perundang-undangan yang sah, dan dikenal dalam sistem perundang-undangan Indonesia. Kemudian setelah dikeluarkannya Perpu tersebut sebagai perubahan Undang-Undang yang lama dengan demikian apabila Perpu tersebut menjadi UndangUndang maka harus melalui mekanisme untuk mendapat persetujuan DPR (Dewan Perwakilan Rakyat) agar disahkan menjadi Undang-Undang dan dikarenakan DPR menyetujui hal tersebut maka sahlah Perpu tersebut menjadi Undang-Undang Nomor 2 tahun 2017. Namun ada catatan khusus yang menjadikan Undang-Undang ini tidak mencerminkan negara yang menjunjung tinggi demokrasi yakni proses pembentukan Undang-Undang ini tidak melalui hal yang demokratis walaupun Undang-Undang ini berasal dari hak konstitusional Presiden namun hal itu masih menjadi tanda tanya dikarenakan hal kegentingan apa yang mendasari lahirnya Perpu yang kemudian disahkan DPR menjadi sebuah Undang-Undang, Walaupun disahkan oleh DPR seharusnya meperhatikan gagasan demokrasi yang menuntut agar setiap bentuk undang-undang dan berbagai keputusan mendapatkan persetujuan dari wakil rakyat dan sebanyak mungkin memperhatikan kepentingan rakyat.

Gagasan negara hukum menuntut agar penyelenggaraan kenegaraan dan pemerintah harus didasarkan kepada undang-undang dan memberikan jaminan terhadap hak-hak dasar terhadap rakyat yang tertuang dalam undang-undang. Namun dasar lahirnya Nomor 2 tahun 2017 sudah menimbulkan potensi kesewenang-wenangan, dikarenakan hukum yang dibuat mencerminkan kekuasaan semata yang dimana hukum dibuat, ditetapkan dan ditafsirkan serta ditegakkan berdasarkan tangan besi dan merupakan pandangan subjektif dari si pemegang kekuasaan tanpa memperhatikan hal-hal yang memang merupakan dasar demokrasi yakni masyarakat. Di era pemerintahan presiden Joko Widodo nampaknya berusaha memperlemah potensi persatuan umat Muslim melalui kebijakan devide et empera (politik pecah belah) dengan mengakomodasi kepentingan dan aspirasi sebagian kelompok Muslim, dan mengabaikan kelompok Muslim lain. Pengakomodasian paham keagamaan dalam struktur negara, yang diakitkan dengan aspirasi komunitas Muslim tertentu adalah gambaran dari politik pecah belah dimaksud, Karena kenyataannya mengundang reaksi ketidaksetujuan dari komunitas Muslim yang lain. Meskipun kemungkinan reaksi itu sudah diketahui oleh rezim penguasa, 
tetapi hal itu tidak menyurutkan niat pemerintah untuk mengeluarkan keputusan tersebut. Hal ini dinilai oleh sebagian kalangan sebagai bukti kebenaran tujuan kebijakan ini, yakni terbelahnya kekuatan Muslim (Jaunuri, 2016: 41).

Menurut Undang-Undang Nomor 2 tahun 2017 tentang Ormas, sebuah Ormas dapat didirikan oleh 3 (tiga) orang warga Negara Indonesia atau lebih, kecuali Ormas yang berbadan hukum yayasan. Ormas memiliki lingkup: nasional, provinsi, atau kabupaten/kota. Sementara sebuah Ormas juga dibedakan statusnya menjadi dua bagian yakni: pertama, Ormas berbadan hukum merupakan Ormas yang dapat berbentuk perkumpulan atau yayasan. Ormas berbadan hukum perkumpulan didirikan dengan berbasis anggota, sedangkan Ormas berbadan hukum yayasan didirikan dengan tidak berbasis anggota. Badan hukum perkumpulan didirikan dengan memenuhi persyaratan: akta pendirian yang dikeluarkan oleh notaris yang memuat $\mathrm{AD}$ dan $\mathrm{ART}$, program kerja, sumber pendanaan, surat keterangan domisili, nomor pokok wajib pajak atas nama perkumpulan, dan surat pernyataan tidak sedang dalam sengketa kepengurusan atau dalam perkara di pengadilan. Pengesahan sebagai badan hukum perkumpulan dilakukan oleh Menteri yang menyelenggarakan urusan pemerintahan di bidang hukum dan hak asasi manusia. Pengesahan sebagai badan hukum perkumpulan dilakukan setelah meminta pertimbangan dari instansi terkait. Kedua, Ormas tidak berbadan hokum, Ormas ini dapat berbasis anggota atau tidak berbasis anggota. Pendaftaran Ormas yang tidak berbadan hukum dilakukan dengan pemberian surat keterangan terdaftar. Pendaftaran Ormas yang tidak berbadan hukum dilakukan dengan memenuhi persyaratan berikut: akta pendirian yang dikeluarkan oleh notaris yang memuat $\mathrm{AD}$ atau $\mathrm{AD}$ dan ART, program kerja, susunan pengurus, surat keterangan domisili, nomor pokok wajib pajak atas nama Ormas, surat pernyataan tidak dalam sengketa kepengurusan atau tidak dalam perkara di pengadilan, dan surat pernyataan kesanggupan melaporkan kegiatan. Surat keterangan terdaftar diberikan oleh Menteri bagi Ormas yang memiliki lingkup nasional, gubernur bagi Ormas yang memiliki lingkup provinsi, dan bupati/walikota bagi Ormas yang memiliki lingkup kabupaten/kota. Menteri, gubernur, atau bupati/walikota wajib melakukan verifikasi dokumen pendaftaran paling lama 15 (lima belas) hari kerja terhitung sejak diterimanya dokumen 
pendaftaran. Dalam hal dokumen permohonan belum lengkap Menteri, gubernur, atau bupati/walikota meminta Ormas pemohon untuk melengkapinya dalam waktu paling lama 15 (lima belas) hari kerja terhitung sejak tanggal penyampaian ketidaklengkapan dokumen permohonan. Dalam hal Ormas lulus verifikasi, Menteri, gubernur, atau bupati/walikota memberikan surat keterangan terdaftar dalam jangka waktu paling lama 7 (tujuh) hari kerja. Dalam hal Ormas tidak berbadan hukum yang tidak memenuhi persyaratan untuk diberi surat keterangan terdaftar dilakukan pendataan sesuai dengan alamat dan domisili. Pendataan Ormas dilakukan oleh camat atau sebutan lain. Pendataan Ormas meliputi: nama dan alamat organisasi;, nama pendiri, tujuan dan kegiatan, dan susunan pengurus.

Sebelum berlakunya Undang-Undang Nomor 2 Tahun 2017 pembubaran Organisasi masyarakat melalui tahapan-tahapan yang dimana tahapan tersebut melalui peringatan tertulis kedua, peringatan tertulis ketiga, penghentian bantuan/dana hibah. Kemudian kewajiban pemerintah meminta pertimbangan hukum Mahkamah Agung sebelum menghentikan kegiatan sementara ormas atau sebelum menjatuhkan sanksi pencabutan surat keterangan terdaftar dan atau pencabutan status badan hukum. Dan terkait permohonan pembubaran Ormas berbadan hukum yang diajukan ke pengadilan negeri oleh kejaksaan dengan permintaan tertulis dari menteri yang menyelenggarakan urusan pemerintahan di bidang hukum dan hak asasi manusia.

Setelah berlakunya Undang-Undang Ormas Nomor 2 tahun 2017 semua ketentuan sebelumnya telah dihapuskan dimana Undang-Undang ini meniadakan proses pengadilan dalam pembubaran ormas yang dianggap telah bertentangan dengan ideologi Negara, dikarenakan tahapan pembubaran ormas hanya melalui kemenkumham dengan mencabut status badan hukum Ormas yang telah dianggap bertentangan dengan Pancasila yang hanya melewati dua sanksi administratif yaitu peringatan tertulis satu kali dalam janka waktu tujuh (7) hari dan penghentian kegiatan. Dengan demikian status pencabutan badan hukum Ormas ini bersifat langsung atau dengan kata lain pembubarannya dilakukan oleh kemnkumham dan kemendagri selaku pemberi izin dari ormas tersebut. Adapun beberapa pasal perbedaan Pra dan Pasca Undang-Undang Ormas seperti yang terlihat dibawah ini : 
Pertama, Pasal 61 Pasca Undang-Undang Ormas, Sanksi administratif sebagaimana dimaksud dalam Pasal 60 ayat (1) terdiri atas: peringatan tertulis, penghentian kegiatan, dan/atauc pencabutan surat keterangan terdaftar atau pencabutan status badan hukum. Sedangkan, Pasal 61 Pra Undang-Undang Ormas, sanksi administratif sebagaimana dimaksud dalam Pasal 60 ayat (1) terdiri atas: peringatan tertulis, penghentian bantuan dan/atau hibah, penghentian sementara kegiatan, dan/atau pencabutan surat keterangan terdaftar atau pencabutan status badan hukum.

Kedua, Pasal 62 Pasca Undang-Undang Ormas adalah (a) peringatan tertulis sebagaimana dimaksud dalam Pasal 61 ayat (1) huruf a diberikan hanya 1 (satu) kali dalam jangka waktu 7 (tujuh) hari kerja sejak tanggal diterbitkan peringatan, (b) dalam hal Ormas tidak mematuhi peringatan tertulis dalam jangka waktu sebagaimana dimaksud pada ayat (1), Menteri dan menteri yang menyelenggarakan urusan pemerintahan di bidang hukum dan hak asasi manusia sesuai dengan kewenangannya menjatuhkan sanksi penghentian kegiatan, (c) dalam hal Ormas tidak mematuhi sanksi penghentian kegiatan sebagaimana dimaksud pada ayat (2), Menteri dan menteri yang menyelenggarakan urusan pemerintahan di bidang hukum dan hak asasi manusia sesuai dengan kewenangannya melakukan pencabutan surat keterangan terdaftar atau pencabutan status badan hukum. Sedangkan, Pasal 62 Pra Undang-Undang Ormas, peringatan tertulis sebagaimana dimaksud dalam Pasal 61 huruf a terdiri atas: peringatan tertulis kesatu, peringatan tertulis kedua, dan peringatan tertulis ketiga. Penjelasan mengenai ketiga hal tersebut di atas adakah: (a) peringatan tertulis sebagaimana dimaksud pada ayat (1) diberikan secara berjenjang dan setiap peringatan tertulis tersebut berlaku dalam waktu paling lama 30 (tiga puluh) hari, (b) dalam hal Ormas telah mematuhi peringatan tertulis sebelum berakhirnya jangka waktu sebagaimana dimaksud pada ayat (2), pemerintah atau pemerintah daerah dapat mencabut peringatan tertulis dimaksud, (c) dalam hal Ormas tidak mematuhi peringatan tertulis kesatu dalam jangka waktu sebagaimana dimaksud pada ayat (2), Pemerintah atau Pemerintah Daerah dapat menjatuhkan peringatan tertulis kedua, (d) dalam hal Ormas tidak mematuhi peringatan tertulis kedua dalam jangka waktu sebagaimana dimaksud pada ayat (2), Pemerintah atau Pemerintah Daerah dapat 
menjatuhkan peringatan tertulis ketiga

Berdasarkan hal tersebut di atas, bahwasanya pembubaran Ormas tidak lagi melalui mekanisme peradilan, dimana ketika organisasi masyrakat dianggap bertentangan atau mengancam Pancasila, maka secara langsung pembubarannya dapat dilakukan dengan pencabutan izin dari Kementerian terkait baik yang berbadan hukum maupun yang tidak berbadan hukum. Terlihat jelas bahwa Undang-Undang Ormas terbaru menerapkan asas contrarius actus didalamnya yang dimana kewenangan dari suatu Kementerian yang memberikan izin dapat pula mencabut izin tersebut, apabila ditelaah lebih baik bahwasanya status badan hukum yang dimiliki oleh ormas itu tidak dapat dicabut seketika itu juga oleh Kementerian terkait dikarenakan harus melalui proses pengadilan guna menentukan apakah izin tersebut dapat dicabut atau tidak, dengan demikian asas dalam hukum administrasi negara ini ditafsirkan berbeda oleh pembuat undang-undang guna mencapai suatu tujuan yang berbeda pula.

Asas contrarius actus adalah asas yang berasal dari tradisi hukum Romawi yang memberi wewenang kepada pemerintah untuk menarik kembali keputusan/peraturan yang dibuatnya dengan ketentuan bahwa penarikan keputusan peraturan tersebut dilakukan oleh lembaga yang membuatnya. Asas tersebut sebenarnya melekat pada pejabat pemerintah tanpa perlu ditegaskan dalam peraturan perundang-undangan. Sebenarnya setiap pejabat pemerintah dapat menarik kembali keputusan yang dibuatnya walaupun wewenang tersebut tidak disebutkan secara eksplisit dalam peraturan perundang-undangan terkait. Secara umum, asas contrarius actus telah tercantum secara eksplisit dalam pasal 33 ayat 3 Undang-Undang nomor 30 tahun 2014 tentang administrasi pemerintahan. Pencabutan kembali suatu keputusan juga harus mengacu kepada kriteria atau batasan yang telah diatur dalam Undang-Undang Administrasi Pemerintahan, ada cacat wewenang, prosedur dan/atau substansi pasal 64 Undang-Undang Administrasi Pemerintahan (Nalle, 2017). Artinya, asas contrarius actus merupakan asas yang ada dihukum administrasi yang telah termanivestasikan dalam Undang-Undang Ormas, asas tersebut kurang tepat untuk diterapkan dalam Undang-Undang Ormas yang baru, mengingat pemerintah dalam hal ini adalah Kementerian Hukum Dan Hak Asasi Manusia atau Kementerian Dalam Negeri yang mempunyai otoritas 
penuh dalam memberikan izin ataupun membubarkan Ormas tertentu yang dalam pandangannya(subjektif-nonprosedural) menyalahi idiologi bangsa.

Bila didasarkan pada penerapan Asas tersebut, maka terjadi kemunduran dari proses hukum yang berkeadilan terhadap pembubaran suatu Ormas, yang sebenarnya pembubaran Ormas yang harus melalui sistem peradilan namun kenyataannya diambil alih oleh lembaga Kementerian Hukum Dan Hak Asasi Manusia atau Kementerian Dalam Negeri dalam membubarkan Ormas dengan mencabut status badan hukum dari ormas tersebut padahal apabila melihat idealnya penerapan asas contrarius actus sebagaimana apa yang telah dikemukakan diatas bahwasanya asas tersebut berlaku apabila ada cacat wewenang, prosedur, dan/atau substansi dari keputusan kementerian tanpa mendefinisikan lebih lanjut mengenai ruang lingkup larangan bagi ormas. Dengan demikian pencabutan status badan hukum dari Ormas tersebut seyogyanya harus melalui mekanisme peradilan bukan melaui dalih penerapan asas contrarius actus yang lebih cenderung keliru secara normatif. Dengan demikian akan menimbulkan praktek sewenang-wenang dikemudian hari dikarenakan interpretasi mengenai Ormas yang menyalahi aturan hanya bertumpuh pada satu institusi saja.

Di sisi lain, ternyata dalam Undang Undang Ormas telah terjadi terabaikannya due process of law. Konsep due process of law berasal dari english common law yang mendalilkan bahwa seseorang tidak boleh dicabut atau dihilangkan hak hidupnya, kebebasannya dan harta miliknya tanpa pemberitahuan dan kesempatan untuk membela hak-hak mereka yang dijamin oleh konstitusi. Magna Charta, kesepakatan yang ditandatangani pada tahun 1215 antara Raja John dan rakyat kelas atas yang marah (enraged upper classes) antara lain menjelaskan pengertian due process of law sebagai berikut: "No free man shall be sized, or imprisoned..... except by the lwfful judgment of his peers, or by the of the land". Frasa "the law of the land" kemudian ditransformasikan menjadi frasa "due process of law". Berbeda dengan Inggris yang mengembangkan konsep due process of law melalui kebiasaan, di Amerika Serikat konsep ini dikembangkan dalam penetapan dalam hukum tertulis khususnya konstitusi Amerika Serikat.

Due process of law merupakan suatu jaminan konstitusional yang memastikan adanya proses hukum yang fair (adil) yang memberikan 
kesempatan kepada seseorang untuk mengetahui proses tersebut dan memiliki kesempatan untuk didengar keterangannya mengapa hak hidup, kebebasan dan harta miliknya dirampas atau dihilangkan. Hal tersebut adalah jaminan konstitusional yang menegaskan bahwa hukum tidak akan ditegakkan secara tidak rasional, sewenang-wenang (arbitrary), atau tanpa kepastian (capricous). Due process of law adalah prinsip yang mendalilkan bahwa pemerintah harus menghormati hukum, menghormati hak-hak rakyat sebagaimana termaktub di dalam konstitusi, dan melindungi rakyat dari kesewenang-wenangan. Due process of law diyakini memiliki basis filosofis yang menyambung kepada hukum alam (natural law) yang mendalilkan bahwa due process of law tidak lain adalah keadilan yang melekat secara alamiah kepada manusia dalam mempertahankan hak dan kebebasannya (natural justice). Di Amerika Serikat, due process clause Amandemen ke-14 yang diratifikasi pada tahun 1868 menyatakan: "Nor shall any State deprive any person of life, liberty, or property, without due process of law." Kata 'due' dalam hukum Amerika Serikat dimaknai dan dipahami sebagai reasonable (masuk akal), just (adil), dan proper (patut). Kewenangan untuk menentukan adanya proses yang reasonable, just, dan proper terletak pada pengadilan atau The power to decide as to the reasonability of the same is vested in the courts (Latipulhayat, 2017).

Idealnya due process of law, maka pembubaran ormas seyogyanya di dalam Undang-Undang Ormas memberikan kesempatan bagi Ormas yang dianggap telah menyalahi perundang-undangan tersebut untuk melakukan pembelaan melalui mekanisme peradilan yang baik, maka secara tidak langsung prinsip negara hukum yakni due process of law dapat berjalan dengan baik, sekalipun pada tataran kenyataan bahwa negara melalui Undang-Undang yang berawal dari Perpu, kemudian mendapatkan legitimasi untuk dijadikan Undang-Undang secara sah menghilangkan due process of law yang merupakan dasar dari negara hukum yang oleh konstitusi Indonesia mengakui bahwasanya Indonesia adalah negara berdasarkan hukum.

\section{PENUTUP}

Berlakunya Undang-Undang Nomor 2 tahun 2017 tentang Organisasi Kemasyarakatan menimbulkan dampak terhadap demokrasi di Indonesia, dikarenakan Undang Undang tersebut hanya mengakomodir sebagian 
kepentingan yang ada di negara ini dan tidak meperhatikan secara keseluruhan aspirasi masyarakat Indonesia. Bahwa dengan adanya pencantuman asas contrarius actus di dalam Undang Undang tersebut menimbulkan kekeliuruan secara normatif, dikarenakan ormas yang dianggap melanggar ideologi negara hanya dapat dibubarkan secara adil dan benar melalui mekanisme peradilan, apalagi melihat status ormas tersebut telah berbadan hukum. Bahwasanya Undang-Undang No. 2 tahun 2017 telah mengabaikan salah satu prinsip due process of law yang dianut oleh negara hukum yang dimana pembubaran ormas tidak melalui mekanisme peradilan, sehingga Undang Undang ini menutup celah bagi ormas yang dianggap melanggar atau bertentangan dengan ideologi negara untuk melakukan pembelaan diri dihadapan pengadilan. Oleh sebab itu, perlunya dilakukan revisi terhadap Undang-Undang No. 2 tahun 2017 yang dimana Undang-Undang tersebut dipandang perlu untuk mencantumkan kembali pasal mengenai pembubaran yang melalui mekanisme peradilan.

\section{DAFTAR REFERENSI}

Asshiddiqie Jimly, Hukum Tata Negara dan Pilar-Pilar Demokrasi Serpihan Pemikiran Hukum, Media dan HAM, Konstitusi Press, Jakarta, 2006

Huda Ni'matul, Negara Hukum, Demokrasi \& Judicial Review, UII Press, Yogyakarta, 2005

Jaunuri Achmad, Radikalisme dan Terorisme, Intrans Publishing, Malang, 2016

Sarja, Negara Hukum "Teori dan Praktek", Thafa Media, Yogyakarta, 2016

Tim Penyusun PUSLIT IAIN Syarif Hidayatullah Jakarta, Pendidikan Kewarganegaraan Demokrasi, HAM dan Masyarakat Madani, IAIN Jakarta Press, Jakarta, 2000.

Latipulhayat, Due Process Of Law, Padjadjaran Jurnal Ilmu Hukum Vol. 4 Nomor 2 Tahun 2017

Victor Imanuel W. Nalle, Asas Contrarius Actus dalam Perpu Ormas :Kritik dalam Prespektif Hukum Administrasi dan Hak Asasi Manusia, Padjadjaran Jurnal Ilmu Hukum Vol. 4 Nomor 2 (2017).

Sujito, Membaca "Kepentingan Politik Dibalik Perpu Ormas Dan Implikasi Sosiologisnya Pada Masyarakat", Makalah Seminar Quo Vadis Perpu Ormas Tinjauan Kritis Dari Prespektif Sosio Politik, Hukum \& HAM, Yogyakarta, 2017. 